\title{
Analisa Penilaian Soal Fisika Menggunakan Model Rasch Dengan Program R
}

\author{
Made Rai Suci Shanti ${ }^{1,2,}$, Edi Istiyono ${ }^{1}$, \\ Sudji Munadi ${ }^{1}$, Cahyo Permadi ${ }^{2}$, Alvama Patiserlihun ${ }^{2}$, Debora Natalia Sudjipto \\ ${ }^{1}$ Program Studi Penelitian dan Evaluasi Pendidikan Pascasarjana Universitas Negeri Yogyakarta, Jalan \\ Colombo No. 1, Yogyakarta \\ ${ }^{2}$ Program Studi Pendidikan Fisika, Fakultas Sains dan Matematika, Universitas Kristen Satya Wacana, Jalan \\ Diponegoro 52-60, Salatiga
}

*email korespondensi: maderai.2017@student.uny.ac.id

Received : 16 Juli 2020; Revised : 30 Juli 2020; Accepted : 9 Oktober 2020; Published : 16 Oktober 2020

\section{ABSTRAK}

Penilaian hasil pembelajaran dibutuhkan untuk membuat keputusan dalam pembelajaran. Banyak pengajar mengabaikan cara penilaian hasil belajar, dengan soal-soal yang tidak mencerminkan kemampuan siswa. Penelitian ini memberikan sebuah contoh cara menganalisa soal Fisika yang digunakan untuk mengukur kemampuan siswa dengan tepat. Banyak tehnik penilaian sudah dikembangkan untuk menilai pencapaian kompetensi hasil belajar siswa. Analisa teori respon butir atau Item Response Theory (IRT) merupakan salah satu analisa yang dapat digunakan untuk melihat ketepatan soal. Penelitian ini akan menggunakan pendekatan model Rasch. Model Rasch mengacu pada tingkat kesulitan butir soal (b) tiap item soal, dan daya beda butir soal (a) yang sama untuk seluruh item soal. Analisa butir soal menggunakan 16 butir soal Fisika pada media pembelajaran Fun Frame in Physics (FFP). Butir soal diujikan kepada 99 siswa SMP dan dianalisa menggunakan program R, dengan hasil daya beda butir soal (a) sebesar 0,815, tingkat kesulitan butir rata-rata ( brata2) $_{2}$-0,331 dengan standar deviasi 1,232552. Hasil pengkategorian soal didapatkan, soal dikatakan sangat sulit jika $b>0,902$, soal dikatakan sulit jika $-0,331<b<0,902$, soal dikatakan mudah jika $-1,564<b<-0,331$ dan soal dikatakan sangat mudah jika $b<-1,564$. Kesimpulan tigkat kesulitan soal FFP adalah $25 \%$ soal sangat mudah, $37,5 \%$ soal mudah, $12,5 \%$ soal sulit, dan $25 \%$ soal sangat sulit. Karakeristik butir soal ditampilkan juga dalam bentuk fungsi informasi.Grafik fungsi informasi butir menunjukkankan bahwa gambaran karakteristik soal yang dibangun dari respon siswa terlihat mampu menggambaran kemampuan siswa, tercermin melalui nilai informasi tertinggi untuk tiap soal.

Kata-kata kunci: model Rasch; penilaian; teori respon butir

\section{PENDAHULUAN}

Banyak cara atau tehnik penilaian sudah digunakan untuk menilai pencapaian kompetensi dan hasil belajar peserta didik. Namun tidak semua penilaian hasil belajar Fisika yang dibuat oleh guru atau pengajar mampu mengukur kemampuan peserta didik dengan benar dan tepat (Arini, 2016). Sering terjadi dalam pembelajaran standarisasi penilaian tes tidak diperhatikan, bahkan ketika melakukan pembuatan soal atau pengembangan tes. Standarisasi penilaian yang benar dan dapat dipertaggungjawabkan sering diabaikan oleh para guru dan pengajar. Proses penilaian hasil belajar siswa sering tidak dapat mencerminkan kompetensi yang sudah ditetapkan (Istiyono, 2014). Seharusnya penilaian atau assesment merupakan komponen penting dalam penyelenggaraan pendidikan (Herman, 2016). Karena penilaian tes dalam proses pembelajaran dapat digunakan untuk membuat keputusan pencapaian hasil belajar peserta didik. Hal diatas menjadi latar belakang penelitian ini yang bertujuan untuk memberikan sebuah contoh analisis soal Fisika yang tepat, mengukur karakteristik butir soal dari hasil respon siswa. Penelitian ini diharapkan dapat memberikan manfaat bagi para pengajar atau guru untuk menganalisa soal yang efektif dan tepat dalam menilai hasil belajar siswa.

Penilaian terdiri dari beberapa prosedur sistematis untuk mengumpulkan informasi yang dapat digunakan untuk membuat kesimpulan tentang karakteristik seseorang atau objek. Menurut Fink (2003), penilaian merupakan suatu pernyataan berdasarkan sejumlah fakta untuk menjelaskan karakteristik seseorang atau sesuatu. Penilaian berarti menilai sesuatu (Azwar, 2003), sedangkan menilai mengandung arti mengambil keputusan terhadap sesuatu dengan mendasarkan pada ukuran baik atau buruk, sehat atau sakit, pandai atau bodoh dan lain sebagainya. Berdasarkan definisi tersebut, penilaian dalam bidang pendidikan dapat disimpulkan bahwa sebagai semua aktifitas yang dilakukan oleh pendidik dan peserta didik 
untuk menilai diri mereka sendiri, yang memberikan informasi untuk digunakan sebagai umpan balik untuk memodifikasi aktifitas belajar dan mengajar. Berdasarkan beberapa pendapat diatas, dapat dikemukakan bahwa proses penilaian meliputi pengumpulan informasi tentang tujuan yang ingin dicapai, misalnya pencapaian belajar peserta didik. Penilaian merupakan data yang baik sehingga perlu didukung oleh proses pengukuran yang baik. Dalam sistem evaluasi hasil belajar, penilaian merupakan langkah lanjutan setelah dilakukan pengukuran.

Miller (2012) menyebutkan bahwa penilaian pembelajaran akan menjadi barometer atau alat ukur keberhasilan pendidikan dan dapat menjadi tuas yang mampu mendorong terjadinya perubahan sebuah pendidikan. Hal itu menunjukkan bahwa analisa penilaian soal dapat menilai siswa sesuai dengan apa yang seharusnya dinilai dan dapat menunjukkan bahwa alat atau instrument yang digunakan untuk mengukur tepat seperti kompetensi yang diinginkan. Sehingga hasil dan pengambilan keputusan penilaian memiliki dasar yang objektif.

Pendekatan Item Respon Theory (IRT), merupakan pendekatan pengukuran yang dikembangkan untuk mengatasi kelemahan teori pengukuran klasik. Pada teori pengukuran klasik (classical true score model), menyatakan antara lain karakteristik butir soal tergantung pada kelompok peserta yang mengikuti tes, kemampuan (ability) sebagai nilai kinerja dari yang diamati. Koballa (2010) menyebut bahwa hal ini dapat terjadi apabila kelompok peserta untuk pengujian tes berbeda dengan kelompok peserta yang menjadi sasaran tes. Apabila kemampuan kelompok pada saat tes tergolong rendah, maka butir-butir soal pada tes cenderung menjadi sulit. Sebaliknya, apabila kemampuan kelompok peserta pada saat tes tergolong tinggi, maka butir-butir soal cenderung menjadi mudah. Hal senada diungkapkan oleh Baker (1992) yang menyatakan bahwa teori tes klasik sangat tergantung pada karakteristik peserta yang diukur. Apabila suatu perangkat soal diujikan pada sekelompok peserta yang lain, maka hasil analisisnya akan berubah sesuai dengan karakteristik peserta tes. Kelemahan pendekatan klasik tersebut dapat diatasi oleh pendekatan IRT yang berorientasi pada butir soal (Retnawati, 2014), bukan berorientasi pada perangkat tes. Pendekatan IRT melepaskan keterikatan antara butir soal dengan peserta tes. Karakter peserta tes akan tetap sama walaupun mengerjakan butir yang berbeda. Demikian pula, karakteristik butir soal juga akan tetap sama, walaupun dikerjakan oleh peserta yang berbeda.

Model Rasch menyatakan bahwa probabilitas peserta tes untuk menjawab benar suatu butir soal ditentukan oleh satu karakteristik butir, yaitu indeks kesukaran butir (b). Menurut Hambleton Swaminathan, \& Rogers dalam Mardapi (2016), model Rasch dinyatakan dalam $P_{n i}\left(x_{n i}=1 \mid b_{n} . d_{i}\right)$ yang merupakan probabilitas dari responden $n$ dalam item ke $i$ untuk menghasilkan jawaban betul $(x=1)$ dengan kemampuan responden $b_{n}$ dengan tingkat kesulitan item $d_{i}$. Hal itu dinyatakan dalam persamaan 1.

$$
P_{n i}\left(x_{n i}=1 \mid b_{n} \cdot d_{i}\right)=\frac{e^{\left(b_{n}-d_{i}\right)}}{1+e^{\left(b_{n}-d_{i}\right)}}
$$

Dengan i adalah nilai 1, 2, 3, ..., $\mathrm{n}$ dan $e$ adalah bilangan natural yang nilainya mendekati 2,718

Parameter tingkat kesulitan butir soal $\left(b_{i}\right)$ atau $b$ pada item ke $i$ merupakan titik skala kemampuan agar peluang menjawab benar sebesar $50 \%$. Sehingga dapat dikatakan jika suatu butir tes mempunai parameter $b_{i}=0,25$, mempunyai arti diperlukan kemampuan pada skala, minimal sebesar 0,25 untuk dapat menjawab benar dengan peluang 50\%. Sehingga dapat diartikan jika semakin besar nilai parameter tingkat kesulitan item soal $\left(b_{i}\right)$, maka semakin besar kemampuan yang diperlukan untuk menjawab benar dengan peluang $50 \%$. Sehingga, semakin besar nilai parameter $b_{i}$, maka makin sulit butir soal tersebut

\section{EKSPERIMEN}

Penelitian ini tergolong dalam penelitian deskriptif, yang bertujuan untuk menggambarkan karakteristik soal yang dibuat, sekaligus mengestimasi kemampuan peserta tes berdasarkan respon atau jawaban atas tes yang diberikan. Penelitian dilakukan dengan menggunakan 16 soal Fisika yang diambil dari soal yang digunakan dalam media pembelajaran Fun Frame in Physics (FFP) Gambar 1, dengan materi kelistrikan kemagnetan. 


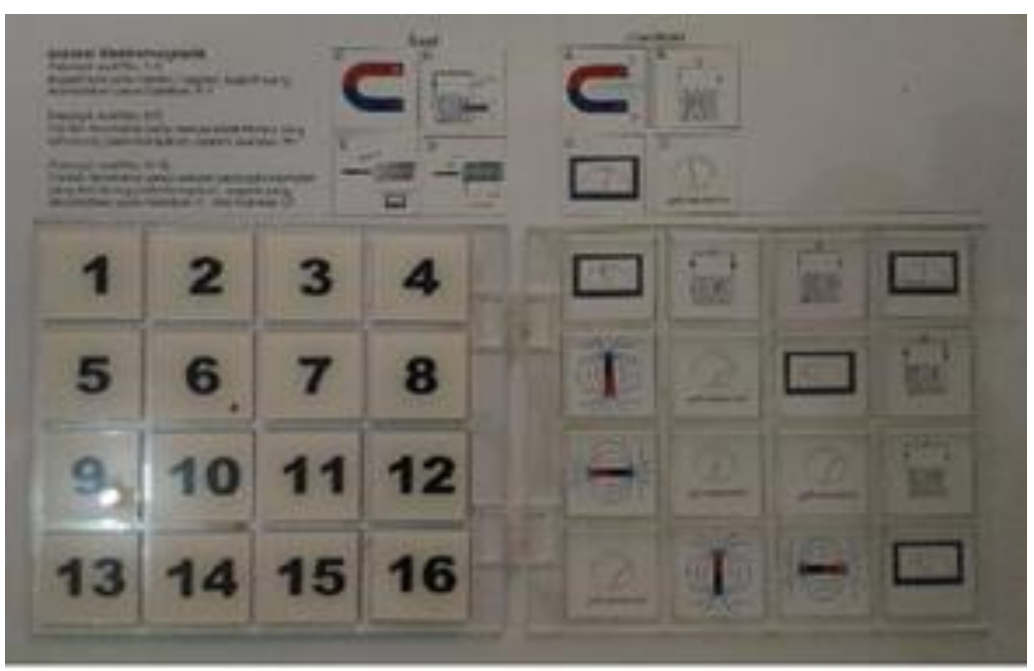

Gambar 1(a). Set media FFP

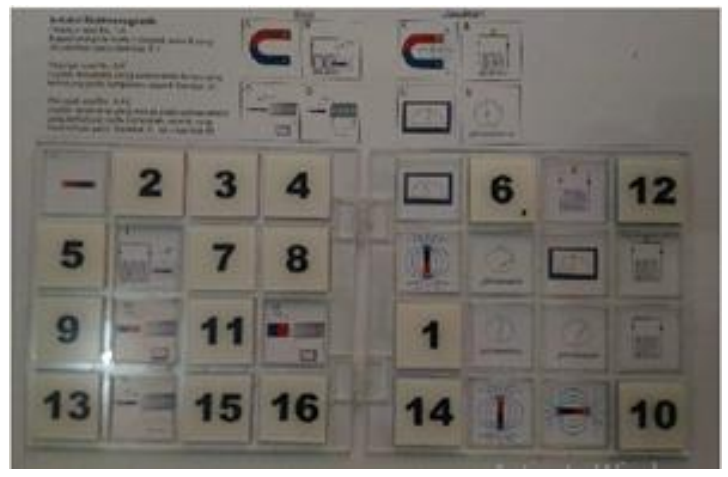

Gambar 1(b). Proses mengerjakan soal

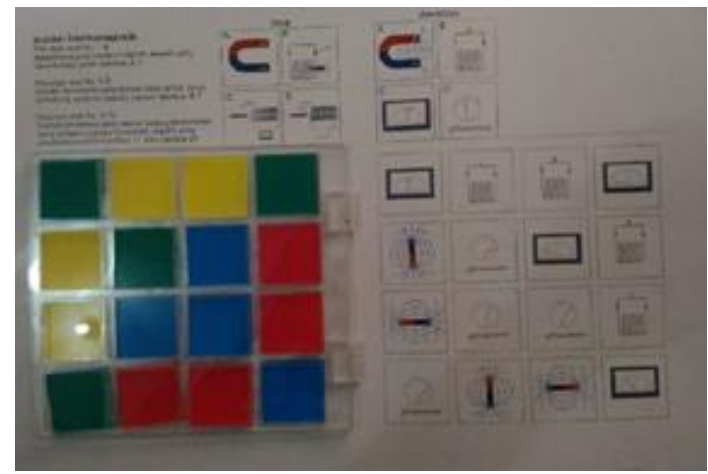

Gambar 1(c). Hasil jawaban siswa yang terlihat lewat pola warna

Gambar 1. Media Fun Frame in Physics

Soal dengan materi kelistrikan dan kemagnetan pada media Fun Frame in Physics (FFP) ini merupakan jenis soal mencocokkan atau menjodohkan gambar. Sisi kiri merupakan sisi soal dan sisi kanan merupakan sisi lembar jawaban. Siswa akan mengerjakan soal dalam media sesuai urutan kotak soal no 1 sampai 16 seperti gambar 1(a). Dengan memindahkan balok no dari sisi soal ke sisi jawaban seperti gambar 1(b). Hasil jawaban siswa dilihat dengan membalikkan frame FFP, sehingga terlihat pola warna seperti pada gambar 1(c). Hasil jawaban siswa akan dikatakan salah jika tidak sesuai dengan kunci pola warna di balik lembar media soal. Soal dikatakan benar jika sesuai dengan kunci yang terdapat pada lembar media. Jawaban benar siswa bernilai 1 dan jawaban yang salah akan bernilai 0 .

Soal tersebut dicobakan pada 99 responden siswa SMP kelas 8 yang berada di beberapa sekolah. Hasil jawaban siswa dicatat dalam pola jawaban dikotomus ( pola 0 dan 1). Berikutnya jawaban responden dianalisa dengan menggunakan Rasch model. Analisa dilakukan dengan pemrograman Rstudio dengan package Itm pada program R sebagai berikut seperti program dibawah ini :

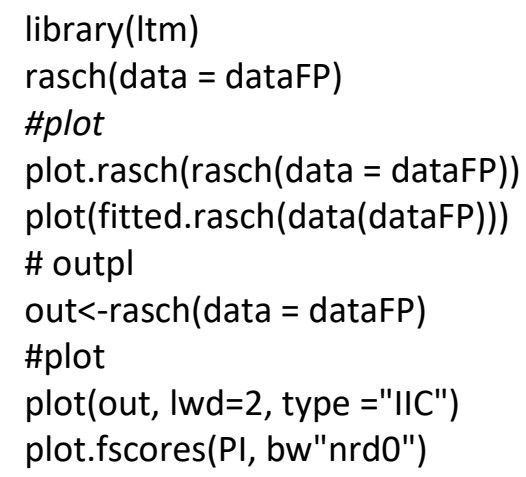

Tahapan program $\mathrm{R}$ ini dapat dijelaskan sebagi berikut, tahap pendefinisian pada baris pertama, baris ke dua dengan penghitungan dengan menggunakan fungsi rasch untuk menghitung daya beda dan tingkat 
kesulitan butir soal, dilanjutkan dengan pencetakan hasil fungsi yang telah di hitung dan penggambaran pada grafik untuk baris ke 3 sampai 6 untuk melihat karakteristik fungsi dari ke 16 butir soal .

\section{HASIL DAN DISKUSI}

Hasil pemrograman yang didapatkan dari analisa Rasch teori untuk mencari tingkat kesulitan setiap soal menggunakan persamaan 1 pada pemrogram $R$ di dapatkan hasil daya beda soal (a) bernilai 0,815 dan tingkat kesulitan soal per butir (b) yang ditampilkan dalam Tabel 1.

Tabel 1. Hasil penghitungan teori Rasch.

\begin{tabular}{cccccc}
\hline Soal ke & Tingkat kesulitan (b) & Ketegori & Soal ke & Tingkat kesulitan (b) & Kategori \\
\hline 1 & -0.451 & mudah & 9 & -2.159 & sangat mudah \\
2 & -0.620 & mudah & 10 & 1.903 & sangat sulit \\
3 & -0.880 & mudah & 11 & -1.453 & mudah \\
4 & 0.455 & sulit & 12 & 0.620 & sulit \\
5 & -1.254 & mudah & 13 & -2.986 & sangat mudah \\
6 & 1.160 & sangat sulit & 14 & -2.207 & sangat mudah \\
7 & 1.066 & sangat sulit & 15 & 1.561 & sangat sulit \\
8 & -1.066 & mudah & 16 & -2.159 & sangat mudah \\
\hline brata2 & $-0,331$ & & & & \\
\hline bstdev & 1,232552 & &
\end{tabular}

Dengan mengacu indeks tingkat kesulitan tiap butir pada Tabel 1 yang mempunyai nilai terendah 2,986 dan tertinggi 1,903, maka rata-rata tingkat kesulitan $\left(b_{\text {rata2 }}\right)$ didapatkan sebesar -0,331 dengan standar deviasi ( $b_{\text {stdev }}$ ) sebesar 1,232552. Pengkategorian soal menurut Sumintono dkk (2015) mengacu pada kriteria yang terdapat pada Tabel 2 di bawah ini:

Tabel 2. Pengkategorian tingkat kesulitan butir.

\begin{tabular}{ccc}
\hline Kriteria & Tingkat kesukaran butir & Kategori \\
\hline$b<\left(b_{\text {rata2- }} b_{\text {stdev }}\right)$ & $b<-1,564$ & sangat mudah \\
$\left(b_{\text {rata2 }}-b_{\text {stdev }}\right)<b<b_{\text {rata2 }}$ & $-1,564<b<-0,331$ & mudah \\
$b_{\text {rata2 } 2}<b<b_{\text {stdev }}$ & $-0,331<b<0,902$ & sulit \\
$b>b_{\text {stdev }}$ & $b>0,902$ & sangat sulit \\
\hline
\end{tabular}

Sehingga didapatkan bahwa 4 butir soal masuk kategori sangat mudah, 6 butir soal termasuk kategori mudah, 2 butir soal masuk kategori sulit dan 4 butir soal termasuk kategori sangat sulit. Dengan sebaran tigkat kesulitan $25 \%$ soal sangat mudah, $37,5 \%$ soal mudah, $12,5 \%$ soal sulit, dan $25 \%$ soal sangat sulit. Maka soal yang terdapat dalam media FFP tersebut dapat digunakan untuk mengukur siswa dengan kemampuan beragam dari siswa yang memahami materi dan siswa yang tidak memahami materi. Soal yang masuk kategori sangat mudah dan berada pada rentang skala kemampuan siswa yaitu -2,986 sampai dengan -0,451 adalah soal tentang pemahaman siswa tentang konsep pengaruh besar medan magnet terhadap jarak, dari batang magnet dan kumparan. Soal yang masuk kategori sulit dan sangat sulit adalah soal dengan skala kemampuan siswa dari 0,455 sampai dengan 1,903 untuk mengetahui pemahaman siswa tentang perubahan medan magnet akan menghasilkan arus listrik yang dilihat dalam indikator galvanometer dan lampu. Soal ini merupakan soal pengembangan dari soal dengan tingkat kesulitan mudah dan sangat mudah.

Gurel (2015) menyatakan bahwa setiap pengukuran seharusnya dapat menyajikan informasi tentang hasil pengukuran. Dalam hal ini informasi yang di ukur bukan informasi tentang individu respondennya melainkan informasi tentang butir soal, dimana informasi tersebut berhubungan dengan soal dan hasil respon siswa terhadap soal tersebut (Mardapi, 2016). Informasi yang didapat memang sangat bergantung dari variasi hasil pengukuran yaitu respon siswa. Sehingga semakin banyak responden akan memberikan variasi real hasil ukur butir soal. Gambar 2 merupakan gambar tentang fungsi Informasi pengukuran ( test information function). 


\section{Item Information Curves}

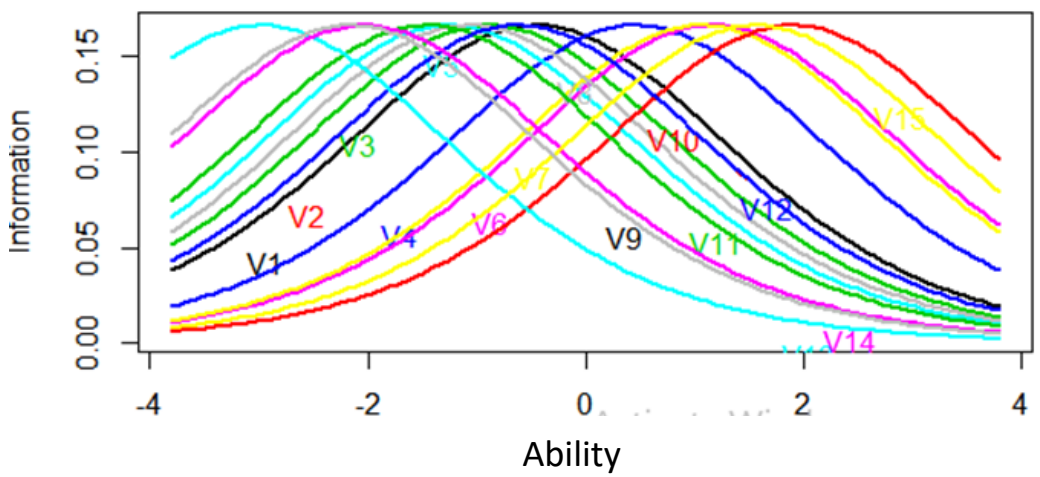

Keterangan gambar

V1: butir soal 1

V5: butir soal $5 \quad$ V9 $\quad$ : butir soal $9 \quad$ V13 : butir no 13

V2: butir soal 2

V6: butir soal 6

V10 : butir soal 10

V14 : Soal no 14

V3: butir soal 3

V7: butir soal 7

V11 : butir soal 11

V15: Soal no 15

V4: butir soal 4

V8: butir soal 8

V12 : butir soal $12 \quad$ V16 : Soal no 16

Gambar 2. Grafik fungsi Informasi pengukuran (test information function).

Sumbu X pada Gambar 2 menunjukkan tingkat kemampuan siswa yang dibuat dalam skala dari sangat rendah ( skala kemampuan atau ability -4), rendah ( skala kemampuan atau ability -2), sedang ( ability 0 ), tinggi (ability 2) dan sangat tinggi (ability 4). Sumbu $Y$ menunjukkan besarnya fungsi informasi yang didapatkan dari hasil item 16 soal. Berikut akan dianalisa tiga grafik fungsi informasi butir yang mewakili kelompok soal untuk butir soal no 1, 10 dan 13 dengan kategori mudah, sedang dan sulit seperti pada Gambar 3(a), 3(b), dan 3(c).

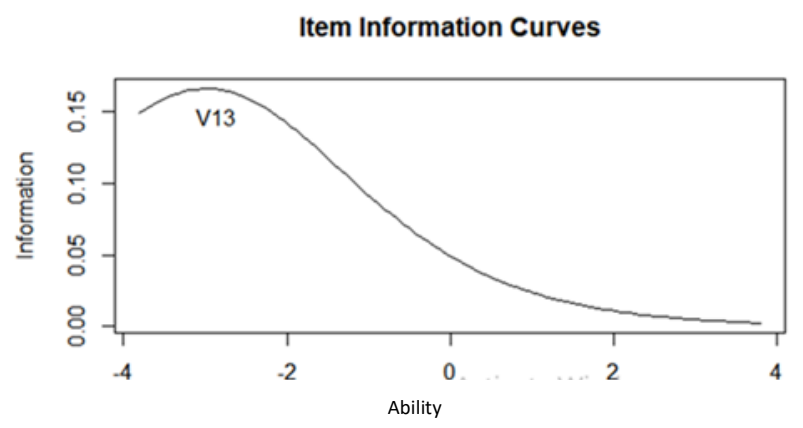

Gambar 3(a). Grafik fungsi informasi butir soal ke 13 dengan kategori sangat mudah.

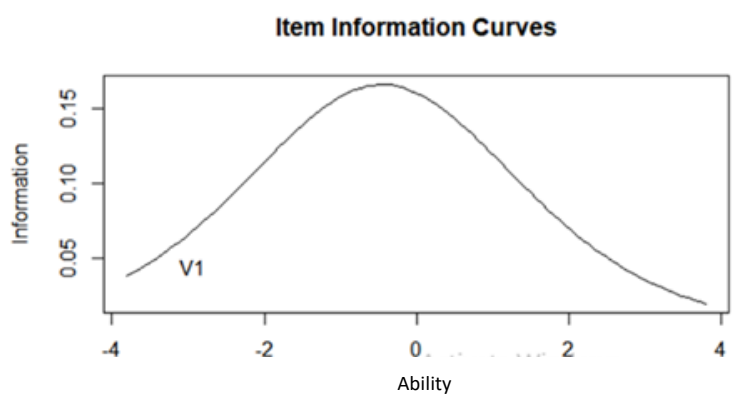

Gambar 3(b). Grafik fungsi informasi butir soal ke 1 dengan kategori sulit.

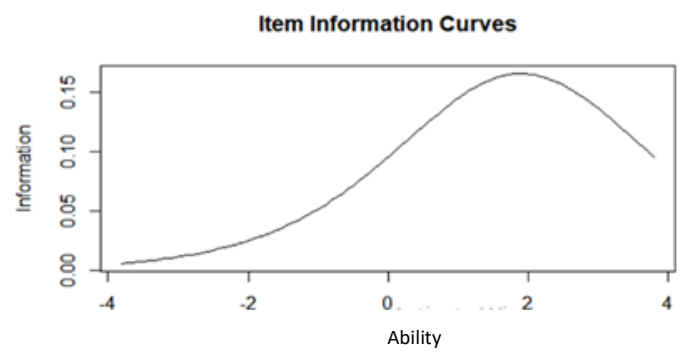

Gambar 3(c). Grafik fungsi informasi butir soal ke 10 dengan kategori sangat sulit.

Butir soal ke 13 (Gambar 4) dibuat dengan tujuan untuk mengetahui pemahaman siswa tentang pengaruh besar medan magnet terhadap pada kumparan kawat, indikator perubahan besar medan magnet dilihat dengan menggunakan perubahan simpangan pada galvanometer, menghasilkan kurva fungsi informasi yang cenderung parabolik di sisi kiri. Hal ini menunjukkan bahwa pada kemampuan siswa yang rendah antara skala -4 sampai -2 ( atau sangat rendah sampai rendah) menghasilkan fungsi informasi yang relative tinggi. Sesuai dengan pernyataan Istiyono (2018) yang menyatakan bahwa nilai informasi merupakan indikasi kemampuan siswa maka soal ini dikatakan mudah karena untuk menyelesaikan soal ini tidak harus 
siswa dengan kemampuan tinggi. Butir tes mempunyai parameter $b=-2.986$, mempunyai arti bahwa untuk menyelesaikan soal ini diperlukan kemampuan siswa pada skala minimal sebesar -2.986 untuk dapat menjawab benar dengan peluang $50 \%$.

Pertanyaan soal no 13 :

Carilah fenomena yang sesuai pada galvanometer yang terhubung pada kumparan

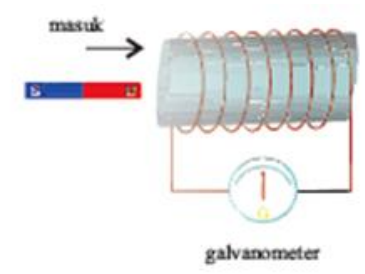

Gambar 4. Butir soal ke 13

Sedangkan butir soal ke 1 (Gambar 5) digunakan untuk mengevaluasi pemahaman siswa tentang pola medan magnet yang benar yang diberi medan magnet. Grafik kurva fungsi informasi yang dihasil parabolik tepat di tengah dengan $b=-0.451$, seperti pada Gambar $\mathbf{3}(\mathbf{b})$, menunjukkan bahwa siswa yang mempunyai kemampuan $b=-0.451$ (sedang) mampu menjawab dengan benar soal tersebut dengan peluang $50 \%$. Hal itu dapat dilihat dari nilai fungsi informasi yang tinggi pada kemampuan skala 0 cukup tinggi, atau dapat diartikan bahwa soal butir 1 , sangat tepat untuk mengukur siswa yang mempunyai kemampuan sedang. Semakin tinggi nilai fungsi informasinya akan semakin baik, karena semakin banyak siswa dengan kategori kemampuan sedang mampu menjawab dengan benar soal tersebut.

Soal butir 1:

Bagaimana pola / medan magnet pada magnet tersebut?

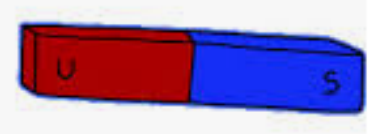

Gambar 5. Butir soal ke 1

Kategori soal berikutnya adalah soal yang sangat sulit yaitu pada butir soal ke 10 (Gambar 6). Soal 10 merupakan soal pengembangan dari soal ke 10 dengan mengubah kecepatan gerak magnet menjadi cepat. Dari hasil grafik fungsi informasi pada Gambar 3(c) yang terlihat berbentuk parabolik yang cenderung ke kanan, menunjukkan bahwa siswa dengan kemampuan tinggi mampu cenderung mampu menjawab benar soal butir ke 10 dengan peluang 50\%, sedangkan siswa dengan kemampuan lebih rendah akan mempunyai peluang menjawab benar soal ini kurang dari $50 \%$. Hal ini ditunjukkan dengan nilai informasi yang tinggi pada skala kemampuan 2.

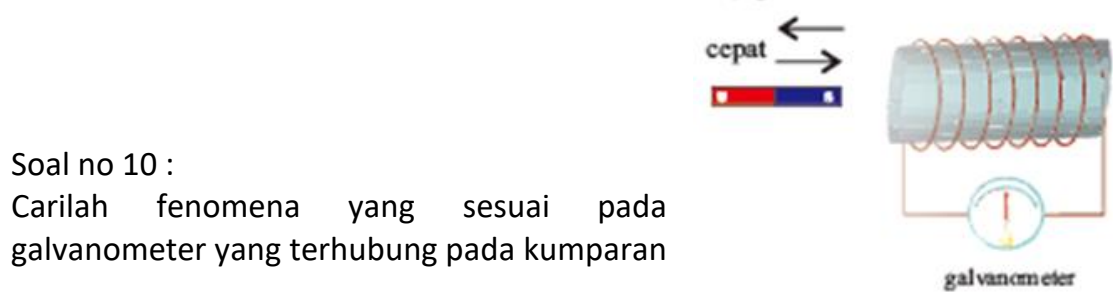

Gambar 6. Soal butir ke 10

Dari keseluruhan analisa butir soal ini didapatkan bahwa dengan menganalisa fungsi informasi butir soal sangat menolong untuk menunjukkan fungsi pengukuran dari soal, dan penganalisaan probabilitas siswa menjawab benar dengan kemampuan tertentu dalam butir soal.

\section{KESIMPULAN}

Dari keseluruhan analisa yang telah dilakukan, maka dapat di simpulkan bahwa dari 16 butir soal yang dianalisa didapatkan 4 butir soal masuk kategori sangat mudah dan mudah Dari keseluruhan analisa yang telah dilakukan, maka dapat di simpulkan bahwa dari 16 butir soal yang dianalisa didapatkan 16 butir soal yang dianalisa didapatkan 4 butir soal masuk kategori sangat mudah yaitu soal butir ke 13,14, dan 16 . Enam butir soal termasuk kategori mudah yaitu butir 1, 2, 3, 5, 8, dan 11. dua butir soal masuk kategori sulit yaitu butir 4 dan 11. Empat butir soal termasuk kategori sangat sulit yaitu butir 6, 7, 10, dan 15. Sebaran tigkat kesulitan soal FFP: $25 \%$ soal sangat mudah, $37,5 \%$ soal mudah, $12,5 \%$ soal sulit, dan $25 \%$ soal sangat sulit. Soal yang terdapat dalam media FFP tersebut dapat digunakan untuk mengukur siswa dengan kemampuan 
beragam dari siswa dengan kemampuan pemahaman rendah sampai dengan siswa dengan kemampuan tinggi.

Informasi kemampuan butir soal akan digambarkan oleh fungsi informasi item yang cenderung mempunya nilai informasi tinggi pada kemampuan tertentu. Informasi tersebut menunjukkan Kecenderungan peluang siswa menjawab benar sebanyak $50 \%$ pada kemampuan tertentu untuk mengerjakan satu butir soal. Sedangkan siswa yang mempunyai kemampuan di atas dan dibawah kemampuan dengan nilai informasi tertinggi mempunyai peluang kurang dari $50 \%$.

\section{DAFTAR PUSTAKA}

Ariani, D., Saptaningrum, E., \& Siswanto, J. (2016). Instrumen Penilaian Keterampilan Kerja Ilmiah pada Pembelajaran Fisika Berbasis Inquiry. Jurnal Penelitian Pembelajaran Fisika , 7, 109-117.

Azwar, S. (2003). Tes prestasi: Fungsi dan pengembangan pengukuran prestasi belajar. Yogyakarta, Pustaka Pelajar.

Baker, F. B. (1992). Item response theory: Parameter estimation techniques. New York, Marcel Dekker.

Fink, L. D. (2003). Creating Significant Learning Experiences : An Integrated Approach to Designing College Courses. San Francisco: John Wiley \& Sons.

Gurel, D., Eryilmaz, A., \& Mc. Dermott, L. (2015). A Review and Comparison of diagnostik Instrumens to Identify Students Misconceptions in Science. Eurasia Jurnal of Mathematics, Science \& Technology Education 11(5), 17-33.

Herman Ari Martono, S. N. (2016). Pengembangan Instrumen Penilaian Hasil Belajar Fisika Kelas X Pada Materi Hukum Newton Dan Penerapannya Berdasakan Kurkulum 2013. Jurnal INKUIRI , 5(3), 155-159.

Istiyono, E. (2014). Pengukuran Kemampuan Berpikir Tingkat Tinggi Fisika Peserta Didik SMA di DIY. Yogyakarta: Disertasi Doktor, Tidak diterbitkan, Universitas Negri Yogyakarta.

Istiyono , E., Mustakim, S. S., Widihastuti, Suranto, \& Mukti, T. S. (2019). Measurment of Physics ProblemSolving Skills in Female And Male Students by PHYSTEPROSS. Indonesian Journal of Science Education, 170-176.

Koballa, T. R. (2010). Science instruction in the middle and secondary school. New York: Pearson Education Inc.

Mardapi, D. (2016). Pengukuran, Penilaian dan Evaluasi Pendidikan. Jogjakarta: Parama Publishing.

Miller, L. D., Robert, L. L., \& Norman, E. G. (2012). Measurment and Assessment Teaching. New York: Pearson Education Ltd.

Retnawati, H. (2014). Teori Respon Butir dan Penerapannya. Yogyakarta: Parama Publishing.

Sumintono, B., \& Widhiarso, B. (2015). Aplikasi Pemodelan Rasch Pada Assessment Pendidikan. Cimahi: Trim Komunikata 